\title{
PREVALENCE AND DETECTION OF GENOTYPE OF HEPATITIS C VIRUS IN CHRONIC RENAL DISEASE PATIENTS UNDERGOING HAEMODIALYSIS IN TERTIARY CARE HOSPITAL IN PUNJAB
}

\author{
Ashish William¹, Aroma Oberoi², Gurvinder Singh Chopra3 ${ }^{3}$ Jasmine Das ${ }^{4}$ \\ ${ }_{1}^{1}$ Post Graduate Resident, Department of Microbiology, Christian Medical College \& Hospital, Ludhiana. \\ 2 Professor, Department of Microbiology, Christian Medical College \& Hospital, Ludhiana. \\ 3 Professor, Department of Microbiology, Christian Medical College \& Hospital, Ludhiana. \\ ${ }_{4}^{4}$ Associate Professor, Department of Nephrology, Christian Medical College \& Hospital, Ludhiana.
}

\begin{abstract}
BACKGROUND

Hepatitis C Virus (HCV) infection is commonest blood borne infection among haemodialysis patients. Despite reduction of Hepatitis $\mathrm{C}$ prevalence after recognition of the virus and testing of blood products, haemodialysis patients still comprise a high risk group. Hepatitis C Virus is detected on the basis of serology, liver function profile and molecular methods. Genotyping is an important tool in epidemiological study, pathogenesis and reaction to antiviral therapy.
\end{abstract}

\section{MATERIALS AND METHODS}

One hundred and seventy six haemodialysed patients (117 male and 59 female) with appropriate symptoms were tested for Hepatitis C Virus infection between January 1, 2013 and February 12, 2016. The minimum volume of whole blood sample was $5 \mathrm{~mL}$ for ELISA and PCR. Detection of Anti-HCV antibodies was done by ELISA by kit from the J. Mitra and Co. Pvt. Ltd. Quantitative detection of HCV-RNA was done by Real Time Polymerase Chain Reaction (RT-PCR) and genotyping done in positive cases.

\section{RESULTS AND DISCUSSION}

Out of 176 Chronic Renal Disease patients 43 (24.43\%) came positive for HCV RNA and 45 patients (25.56\%) came positive for anti-HCV antibody. HCV Genotyping was done in 17 patients, among which 12 patients were positive for genotype 3 (70.58\%), 4 patients for genotype $1(23.52 \%)$ and 1 patient for genotype 4 (5.88\%). Patients with Chronic Renal Disease with HCV Infection had received more number of dialysis sessions (Biweekly) as compared to those without HCV infection. Currently Hepatitis $\mathrm{C}$ virus is most frequently found in patients with chronic renal disease patients undergoing haemodialysis. The diagnosis of HCV is confirmed by detection of HCV-RNA by Polymerase Chain Reaction.

\section{KEYWORDS}

Haemodialysis Patients, HCV, Genotype, PCR, ELISA.

HOW TO CITE THIS ARTICLE: William A, Oberoi A, Chopra GS, et al. Prevalence and detection of genotype of hepatitis C virus in chronic renal disease patients undergoing haemodialysis in tertiary care hospital in Punjab. J. Evolution Med. Dent. Sci. 2016;5(60): 4185-4189, DOI: $10.14260 /$ jemds/2016/955

\section{INTRODUCTION}

Hepatitis C (HCV) infection is a global health issue causing significant morbidity and mortality. The global prevalence of HCV infection is estimated to be $3 \%$ occurring in about 180 million carriers and approximately 4 million people have been newly affected annually.[1] HCV is highly heterogeneous and is classified into eleven genotypes, out of which first six are considered as major source of infection globally.[2-3] The worldwide prevalence of Genotype 3 (54.3 million cases [ $30.1 \%$ of the total]) is considered second most after Genotype 1 with the highest seroprevalence in southern Asia. ${ }^{[4]}$ There is sustainably higher prevalence of anti-HCV antibody among haemodialysis patients than in general population indicating greater risk of getting HCV infection among patients undergoing haemodialysis. Also the mortality and morbidity due to liver disease caused by hepatitis $C$ virus is significant

Financial or Other, Competing Interest: None.

Submission 12-05-2016, Peer Review 17-07-2016,

Acceptance 22-07-2016, Published 27-07-2016.

Corresponding Author:

Dr. Aroma Oberoi,

Professor, Department of Microbiology,

Christian Medical College \& Hospital Ludhiana,

Brown Road, Ludhiana-141008,

Punjab.

E-mail: draromaoberoi@yahoo.com

DOI: $10.14260 /$ jemds/2016/955 among patients with End-Stage Renal Disease (ESRD) undergoing treatment with haemodialysis. [5]

As shown by Dialysis Outcomes and Practice Patterns Study (DOPPS), there has been wide variation in the prevalence of $\mathrm{HCV}$ among different dialysis units and countries with mean HCV prevalence of $13.5 \%$ and variation among countries is $2.6-22.9 \%{ }^{[6]}$ In India, very wide range in the prevalence rate has been reported in dialysis population which is $4.3-45.2 \% .{ }^{[7-8]}$

The risk factors which are considered to be most important for acquisition of HCV infection in dialysis patients include number of blood transfusions and length of time spent on dialysis. The other risk factors in addition are intravenous drug use (Average risk 0-10\%) and history of kidney transplantation (Average risk 28.9-42\%). The risk related to dialysis is estimated to be about $2 \%$, which can vary in countries and the eradication of HCV can be possible by infection control procedures designed for the prevention of blood-borne pathogens.[9] In India the prevalence of HCV infection among Renal Transplant recipients is variable 28.9\%-42\%.[10-11] High prevalence of HCV infection in HD units is a significant risk factor for acquiring HCV infection. The incidence was directly related to the prevalence in the dialysis unit. Units with a prevalence of $<19 \%$ had an annual incidence of $2.5 \%$ compared to a $35.3 \%$ incidence in units with a prevalence $>60 \% .{ }^{[12]}$ 
The standard clinical and serological techniques are not very sensitive and specific in monitoring the diagnosis and rate of progression of chronic hepatitis. Early stages of the infection are missed, because the antibodies develop only after six weeks of infection and the tests for anti-HCV antibody may be negative in the initial period before the sero-conversion occur.[13] For detection of anti-HCV antibody there is current use of third generation ELISA, which has shown greater sensitivity and specificity in patients undergoing haemodialysis.[6] Detection of HCV RNA by reverse transcriptase PCR has been used as the 'gold standard' to identity current HCV infection. ${ }^{[14]}$ Third-generation anti-HCV ELISA is the screening test for the diagnosis of HCV infection. It has shown better performance than the previous two generations of anti-HCV tests with a mean window period of 70 days. The confirmation of HCV is by the detection of HCV RNA in serum by Polymerase Chain Reaction (PCR) assay, which appears earlier than the anti-HCV antibodies by several weeks or months (Becomes detectable 1-3 weeks after exposure).[15-16]

The HCV genotype analysis has not only effect on disease presentation but is also valuable for antiviral therapy, counselling and the proper management.[17] Very few studies have been done in Northern part of country. So this study has been undertaken with the following aim and objectives.

\section{AIMS AND OBJECTIVES}

1. To study prevalence of Hepatitis C Virus (HCV) infection by ELISA, Real Time Polymerase Chain Reaction in Chronic Renal Disease patients undergoing haemodialysis in tertiary care hospital.

2. To study prevalence of genotype of Hepatitis C Virus (HCV) in these positive patients.

\section{MATERIALS AND METHODS}

All patients after ethical clearance were briefed about the study and willing consent was signed. One hundred and seventy six haemodialysed patients ( 117 male and 59 female) with appropriate symptoms were tested for Hepatitis C Virus (HCV) infection between January 1, 2013 and February 12, 2016. The studied population ranged in age from 30 years to 75 years (Average 67.5 years). The samples taken will be Blood serum (For ELISA) or plasma (For PCR). The minimum volume of sample was $5 \mathrm{~mL}$ for ELISA and PCR. From $5 \mathrm{~mL}$ of blood 2-3 $\mathrm{mL}$ of plasma or serum were used for the test. Blood was aseptically collected in sterile vacutainers and processed for detection of Anti-HCV antibody by ELISA. If the test is positive for ELISA (Seropositive), it will be further tested for HCV-RNA viral load by real time PCR. Detection of Anti-HCV antibodies was done by ELISA by kit from the J. Mitra and Co. Pvt. Ltd. (Sensitivity: 100\%, Specificity: 99.73\%). The third generation HCV Microlisa, a qualitative enzyme-linked immunosorbent assay and was used for the detection of antibodies against HCV (Anti-HCVs) in serum or plasma.

Quantitative detection of HCV-RNA was done by Real Time Polymerase Chain Reaction (RT-PCR) and genotyping done in positive cases.

HCV-RNA was quantified using standard RNA extraction and real time amplification kits using Taqman principle along with quantitation standards.

\section{ANTI-HCV}

Detection of Anti-HCV antibodies were done by third generation Enzyme-Linked Immunosorbent Assay (ELISA) by the kit from the J. Mitra and Co. Pvt. Ltd. (Sensitivity: 100\%, Specificity: 99.73\%). Specimens with absorbance values less than or more than the cut-off value will be considered nonreactive and reactive respectively. The test was performed as per the manufacturer's instructions. Diluted sample and controls are incubated at $37^{\circ} \mathrm{C}$ for 30 minutes. Antibodies to HCV if present bind to the immobilized HCV antigens on the microwell during this incubation period. The microwells are then thoroughly washed with the diluted wash buffer to remove excess of unbound anti-HCV or other human IgGs, which may interfere with the test. An enzyme conjugate, antihuman IgG conjugated with HRPO is added. The excess of enzyme conjugate is again removed with diluted wash buffer. At this stage the microwells hold only the bound antigen - antiHCV-enzyme conjugate complex. In the next step, the freshly prepared substrate solution is incubated with the complex in the microwells. The enzyme substrate reaction leads to development of a blue colour, which is indicative of the Antigen-Antibody reaction which has occurred in the microwell. In the final step the Stop Solution is added and the optical density of the developed colour is read photometrically.

\section{HCV-RNA PCR}

HCV-RNA was quantified using standard RNA extraction and real time amplification kits using Taqman principle along with quantitation standards. During PCR, forward and reverse primers hybridise to a specific sequence product. A Taqman probe, which is contained in the same reaction mixture and which consists of an oligonucleotide labelled with a 5'reporter dye and a downstream, 3'-quencher dye, hybridizes to a target sequence within the PCR product. A Taq polymerase which possesses 5' - 3' exonuclease activity cleaves the probe. The reporter dye and quencher dye are separated upon cleavage, resulting in the increase in fluorescence for the reporter. Thus, the increase in fluorescence is directly proportional to the target amplification during PCR.

\section{Inclusion Criteria}

Adult patients of Chronic Renal Disease undergoing haemodialysis were recruited for study.

\section{Exclusion Criteria}

All other confirmed patients of hepatitis including alcohol and drug-induced hepatitis (Anti-tubercular drugs, halothane) were excluded.

\section{RESULTS}

A total of 176 Chronic Renal Disease patients (117 male and 59 female patients with average age of 67.5 years) who underwent haemodialysis were tested, out of which 45 patients (25.56\%) came positive for anti-HCV antibody and 43 (24.43\%) came positive for HCV RNA; 25 patients (18.79\%) were anti-HCV antibody positive, but negative for HCV RNA; 10 patients $(23.25 \%)$ were anti-HCV negative but positive for HCV RNA. HCV Genotyping was done in 17 patients among which 12 patients were positive for genotype 3 (70.58\%), 4 patients for genotype $1(23.52 \%)$ and 1 patient for genotype 4 (5.88\%). 
Patients with Chronic Renal Disease with HCV Infection had received more number of dialysis sessions (Biweekly) as compared to those without HCV infection. In this retrospective study, we studied the prevalence of kidney disease patients having hepatitis $\mathrm{C}$ infection, who were admitted to our hospital for haemodialysis [Table 1] [Figure 1]. The distribution of patients according to the number of dialysis showing the increase in the prevalence of HCV infection with the increase in the number of dialysis as seen in [Table 2] [Figure 2]. The patients who underwent $>100$ or $50-100$ haemodialysis have greater number of Anti-HCV positive cases as compared to $<50$ dialysis patients.

\begin{tabular}{|c|c|c|}
\hline \multicolumn{2}{|c|}{ HCV Test } & \multicolumn{2}{c|}{ Number (Sample Size 176) } \\
\hline Anti-HCV Positive & $45(25.56 \%)$ \\
\hline \multicolumn{2}{|c|}{ HCV RNA Positive } & $43(24.43 \%)$ \\
\hline HCV RNA Negative & $133(75.56 \%)$ \\
\hline Anti-HCV & HCV RNA & 20 \\
Positive & Positive & $(46.51 \%)$ \\
\hline Anti-HCV & HCV RNA & 25 \\
Positive & Negative & $(18.79 \%)$ \\
\hline Anti-HCV & HCV RNA & 10 \\
Negative & Positive & $(23.25 \%)$ \\
\hline \multicolumn{2}{|c|}{ Table 1: Distribution of HCV in Haemodialysis } \\
Patients in Tertiary Care Hospital in Punjab \\
\hline
\end{tabular}

\begin{tabular}{|c|c|c|c|}
\hline $\begin{array}{c}\text { Number of } \\
\text { Dialysis }\end{array}$ & $<\mathbf{5 0}(\mathbf{1})$ & $\mathbf{5 0 - 1 0 0}(\mathbf{2})$ & $>\mathbf{1 0 0}(\mathbf{3})$ \\
\hline $\begin{array}{c}\text { HCV RNA } \\
\text { Positive }\end{array}$ & $\begin{array}{c}9 \\
(20.93 \%)\end{array}$ & $\begin{array}{c}13 \\
(30.23 \%)\end{array}$ & $\begin{array}{c}21 \\
(48.83 \%)\end{array}$ \\
\hline $\begin{array}{c}\text { Anti-HCV } \\
\text { Positive }\end{array}$ & $9(20 \%)$ & $\begin{array}{c}17 \\
(37.77 \%)\end{array}$ & $\begin{array}{c}19 \\
(42.22 \%)\end{array}$ \\
\hline $\begin{array}{c}\text { Table 2: Distribution of HCV in Haemodialysis Patients } \\
\text { According to Number of Dialysis in Tertiary } \\
\text { Care Hospital in Punjab }\end{array}$ \\
\hline
\end{tabular}

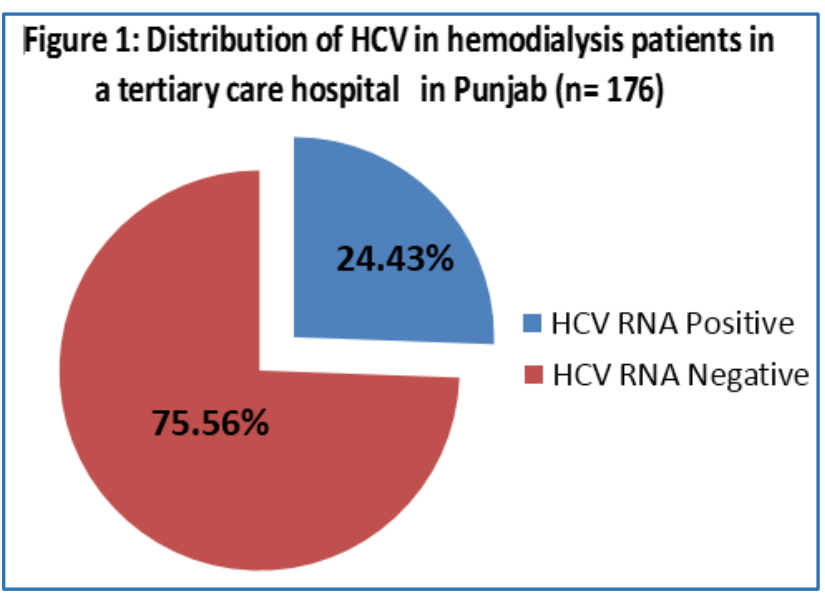

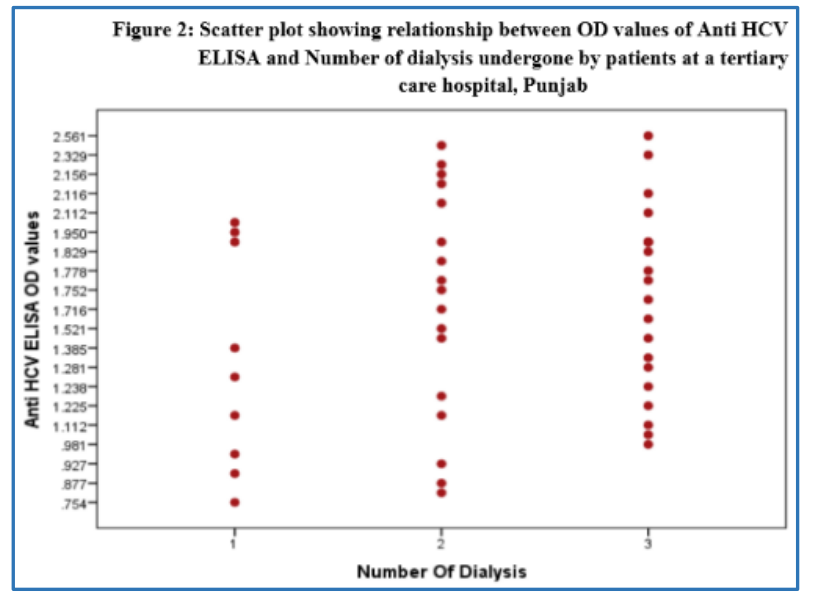

\section{In Figure 2}

1. $<50$ (Patients who underwent less than 50 dialysis).

2. 50-100 (Patients who underwent 50-100 dialysis).

3. $>100$ (Patients who underwent $>100$ dialysis).

\section{DISCUSSION}

Haemodialysis patients are at high risk for the development of hepatitis $\mathrm{C}$ infection. There is inadequate data about the prevalence of HCV infection in haemodialysis patients. In a study done in Andhra Pradesh, the prevalence of HCV infection among haemodialysis patients is $23.5 \%$ with viraemia of 18.01\%.[18] A study in Mexico shows HCV viraemia in 5\% patients with anti-HCV prevalence of $6.7 \% .{ }^{[19]}$ In a study in Brazil, the prevalence of anti-HCV was found to be $39 \% .{ }^{[20]}$ In the current study, the HCV viraemia was found to be $23.3 \%$ with anti-HCV prevalence of $35.7 \%$ among haemodialysis patients. Also according to the current study, the length of time spent on dialysis has contributed to the prevalence of HCV infection.

The tests for anti-HCV antibody may be negative in the initial period before the sero-conversion occur, therefore there are negative results in serology in spite of HCV viraemia in haemodialysis patients. ${ }^{[21]}$ In our study, $23.25 \%$ patients were anti-HCV negative despite the presence of HCV viraemia.

The tests may be with positive serology and negative viraemia which occurs both in immunosuppressed and immunocompetent state. This occurs as a result of three factors - non-establishment of carrier state (Commonly seen in renal transplant patients), whereas other two factors like low level of undetectable viraemia and intermittent viraemia are seen in dialysis settings.[21-22] In current study, HCV viraemia was not detectable in 25 patients with positive serology. Several physiopathogenetic mechanisms have been proposed to explain the intermittent HCV viraemia, like heparin interference with the PCR assay used for the detection of HCV RNA.[23] mechanical extraction of viral particles adhering to dialyzer membrane.[24] and induction of interferon production, hepatocyte growth factor or other cytokines with antiviral properties by the haemodialysis procedure.[25]

Genotype 1 is most prevalent followed by genotype 3 worldwide (30.01\% of total) and its seroprevalence is highest in Southern Asia. In patients of United States, the prevalent major HCV genotypes are genotypes $1 \mathrm{a}$ and $1 \mathrm{~b} .{ }^{[26]}$ In our study, HCV genotype 3 was found to be most predominant (70.58\%) followed by genotype 1 (23.52\%). 
The level of kidney function in the CKD population plays a crucial role on the pharmacokinetics of antiviral drugs targeted at HCV. Kidney filtration and catabolism have a significant contribution to the clearance of IFN and ribavirin; thus, there is the need to make appropriate dosing adjustment and caution.[27]

Currently, Hepatitis C virus is most frequently found in patients with Chronic Renal Disease patients undergoing haemodialysis. Third-generation anti-HCV ELISA is the screening test for the diagnosis of HCV infection. It has shown better performance than the previous two generations of antiHCV tests with a mean window period of 70 days.[28]

The duration of therapy depends on the genotype of the Hepatitis C virus. Combined therapy with both pegylated interferon and ribavirin will have to be given for 24 weeks in genotype 3 patients and 48 weeks genotype 1 patients. The sustained response is less in case of genotype 1 as compared to genotype 3. Systemic screening of ALT and anti-HCV in haemodialysis patients is strongly recommended (Monthly for ALT and 6 monthly for anti-HCV). The diagnosis of HCV is confirmed by detection of HCV-RNA by Polymerase Chain Reaction.

\section{CONCLUSION}

In the present study, it was seen that duration and frequency of dialysis is significantly longer among HCV positive patients as compared to HCV negative patients. Attention should be given to strict adherence to infection control measures in dialysis setting. All dialysis unit should apply universal precautions and use dedicated dialysis equipment for antiHCV positive patients. It is important for the designers of dialysis units to create an environment that makes infectioncontrol procedures easy to implement. Adequate handwashing facilities must be provided and the machines and shared space should make it easy for staff to visualize individual treatment stations.

\section{REFERENCES}

1. Umar M, Bushra HT, Ahmad M, et al. Hepatitis C in Pakistan: a review of available data. Hepat Mon 2010;10(3):205-14.

2. Carithers RL, Marquardt A, Gretch DR. Diagnostic testing for hepatitis C. Semin Liver Dis 2000;20(2):159-71.

3. Waheed Y, Shafi T, Safi SZ, et al. Hepatitis C virus in Pakistan. A systematic review of prevalence, genotypes and risk factors. World J Gastroenterol 2009;15(45):5647-53.

4. Lyra AC, Ramrakhiani S, Bacon BR, et al. Infection with hepatitis $C$ virus genotype 4 in the United States. J Clin Gastroenterol 2004;38(1):68-71.

5. Fabirizi F, Lunghi G, Raffaele L, et al. Serologic survey for control of hepatitis $\mathrm{C}$ in haemodialysis patients: thirdgeneration assays and analysis of costs. Nephrol Dial Transplant 1997;12(2):298-303.

6. Fissell RB, Gresham BJL, Woods JD, et al. Patterns of hepatitis $\mathrm{C}$ prevalence and seroconversion in haemodialysis units from three continents: the DOPPS. Kidney Int 2004;65(6):2335-42.

7. Chawla NS, Sajiv CT, Pawar G, et al. Hepatitis B and C virus infections associated with renal replacement therapy in patients with end-stage renal disease in a tertiary care hospital in India-prevalence, risk factors and outcome. Indian J Nephrol 2005;15(4):205-213.
8. Agarwal SK, Dash SC, Irshad M. Hepatitis C virus infection during haemodialysis in India. J Assoc Physicians India 1999;47(12):1139-43.

9. Chattopadhyay S, Rao S, Das BC, et al. Prevalence of transfusion transmitted virus infection in patients on maintenance haemodialysis from New Delhi, India. Haemodial Int 2005;9(4):362-6.

10. Kidney disease improving global outcomes. Clinical practice guidelines for the prevention, diagnosis, evaluation, and treatment of hepatitis $\mathrm{C}$ in chronic kidney disease. Kidney International 2008;73(Suppl 109):S1-99.

11. Radhakrishnan S, Abraham $P$, Raghuraman S. Role of molecular techniques in the detection of HBV-DNA and HCV-RNA among renal transplant recipients in India. Indian J Med Res 2000;111:204-11.

12. Agarwal SK, Dash SC, Irshad M, et al. Impact of hepatitis C virus infection on renal transplant outcome in India-a single centre study. J Assoc Physicians India 2000;48(12):1155-9.

13. Santos DJP, Loureiro A, Neto CM, et al. Impact of dialysis room and reuse strategies on the incidence of hepatitis $C$ virus infection in haemodialysis units. Nephrol Dial Transplant 1996;11(10):2017-22.

14. Reddy AK, Dakshinamurty KV, Lakshmi V. Utility of core antigen ELISA in the screening of HCV virus infection in patients on haemodialysis. Indian J Med Microbiol 2006;24(1):55-7.

15. Saab S, Brezina M, Gitnick G, et al. Hepatitis C screening strategies in haemodialysis patients. Am J Kidney Dis 2001;38(1):91-7.

16. Uyttendaele S, Claeys H, Mertens W, et al. Evaluation of third-generation screening and confirmatory assays for HCV antibodies. Vox Sang 1994;66(2):122-9.

17. Messina JP, Humphreys I, Flaxman A, et al. Global distribution and prevalence of hepatitis $\mathrm{C}$ virus genotypes. Hepatology 2015;61(10):77-87.

18. Ahmad W, Ijaz B, Javed FT, et al. HCV genotype distribution and possible transmission risks in Lahore, Pakistan. World J Gastroenterol 2010;16(34):4321-8.

19. Sa'nchez NM, Kuba DM, Tapia NCC, et al. Prevalence of hepatitis $\mathrm{C}$ virus infection among haemodialysis patients at a tertiary-care hospital in Mexico city, Mexico. J Clin Microbiol 2004;42(9):4321-2.

20. Carneiro MA, Martins RM, Teles SA, et al. Hepatitis C prevalence and risk factors in haemodialysis patients in central Brazil: a survey by polymerase chain reaction and serological methods. Mem Inst Oswaldo Cruz 2001;96(6):765-9.

21. Chigurapati P, Subbarayudu S, Babu S. Study of incidence of hepatitis $C$ virus infection in haemodialysis patients. Ann Trop Med Public Health 2014;7(3):167-70.

22. Chopra GS, Gupta RM, Gedela SR, et al. Hepatitis C virus infection in haemodialysis patients: wolf in sheep's clothing. MJAFI 2005;61(3):241-4.

23. Chan TM, Lok AS, Cheng IK, et al. Prevalence of HCV infection in dialysis patients: a longitudinal study comparing the results of RNA and antibody assays. Hepatology 1993;17(1):5-8.

24. Satsangi J, Jewell DP, Welsh K, et al. Effect of heparin on polymerase chain reaction. Lancet 1994;343(8911): 1509-10. 
25. Rampino T, Libetta C, Mazzone A, et al. Hepatocyte growth factor protects the liver against hepatitis $\mathrm{C}$ virus in patients on regular haemodialysis. J Chemother 1998;10(2):164-6.

26. Fabrizi F, Messa P, Martin P. Impact of haemodialysis therapy on hepatitis $C$ virus infection: a deeper insight. Int J Artif Organs 2009;32(1):1-11.
27. Pawlotsky JM. Hepatitis $\mathrm{C}$ virus genetic variability: pathogenic and clinical implications. Clin Liver Dis 2003;7(1):45-66.

28. Bush MP, Korelitz JJ, Kleinman SH, et al. Declining value of alanine aminotransferase in screening of blood donors to prevent post-transfusion hepatitis B and C virus infection. The retrovirus epidemiology donor study. Transfusion 1995;35(11):903-10. 